\title{
Effect of sex and season on serum biochemical constituents and enzymes of Panthera leo of Nandankanan Zoological Park
}

\author{
Prakash Chandra Behera ${ }^{1}$, Debabrata Dash ${ }^{1}$, Manas Ranjan Senapati ${ }^{2}$, Purna \\ Chandra Bisoi ${ }^{2}$ and Subas Chandra Parija ${ }^{3 *}$ \\ 1, 2, (Department of Veterinary Biochemistry) \\ ${ }^{3}$ (Department of Veterinary Pharmacology and Toxicology) College of Veterinary Science and Animal \\ Husbandry Orissa University of Agriculture and Technology Bhubaneswar, Odisha, India-751003
}

\begin{abstract}
The study aims to generate blood biochemical reference data as required for diseases diagnosis of lions (Panthera leo). The project was conducted in three regimens of effect of season on male, female and both the sex to determine the variations. Experimental lions of control (12 numbers) and test (6 numbers) groups were selected randomly in the population. Female lions in winter season depicted significantly $(p<0.01)$ higher activity of ALP and lower levels $(p<0.001)$ of glucose and protein but, in summer season they exhibited significantly higher $(p<0.05)$ levels of urea. The comparative study in both the sexes and seasons revealed that, female lions had significantly higher blood glucose (29.06\%) in summer and significantly lower levels of protein (10.98\%) and urea (10.34\%) in winter season. In case of ALP study, it was significantly higher in both male (61.09\%) and female (102.37\%) in winter season. The study concludes that, glucose, protein, urea, and ALP varied significantly with sex and season and must be taken into consideration during interpretation of clinical findings for disease diagnosis.
\end{abstract}

Keywords: Panthera leo, season, sex, biochemical constituents, enzymes

\section{Introduction}

Declined population of wild fauna may result in extinction of many species in near future due to extensive deforestation and destructive man made activities like poaching. Nutritional deficiency, metabolic and infectious diseases also significantly contribute to the cause. The scavenging behavior of wild animals spreads infectious diseases and increases mortality rate [1]. In due course of time, environmental and genetic mutations of pathogens adversely affect the population growth of wild animals. So absolute diagnosis of diseases checks outbreaks, mortality and helps in preserving wild and endangered species. Clinical biochemistry, with samples from body secretions/ excretions and metabolites/ byproducts plays a crucial role in diagnosis of diseases in the laboratory.

Blood, the liquid connective tissue bathes all the cells and transports metabolites, electrolytes, enzymes, hormones and byproducts. So, blood biochemistry is an indispensable factor for indirect and rapid diagnosis of disease everywhere. Knowledge of clinical base line data of different species of animals in various geographical regions, climatic and physiological conditions is essential for absolute diagnosis and treatment [2].

Normal values of blood biochemical parameters in wild and captured animals are not only scanty but in an unsystematic manner also. So, a systematic study with respect to sex, season, region, and climate is essential to generate reference data on wild animals.

Nanadankanan Zoological Park (NZP) near Bhubaneswar, capital of Odisha, is famous for preservation of animals and birds in natural environment at coastal region of eastern India. The project aims to study the blood biochemical constituents of lions of both the sexes in summer and winter season to add a step in clinical biochemistry for laboratory diagnosis of diseases.

\section{Materials and Methods}

\subsection{Study area and experimental animals}

The study was conducted on lions (Panthera leo) of NZP, Bhubaneswar, Odisha, India, located $20 \mathrm{~km}$ from the heart of the city. Apparently healthy lions of both sexes were selected as per zoo record excluding abnormal animals of underweight, gravidity and sickness. Adult lions of more than five years of age weighing $120-140 \mathrm{~kg}$ (female) and 160-200 kg (male) were randomly selected and divided into seven experimental groups consisting of 6 animals in test and 12 in control groups basing on sex and season. The groups were Gr-A: Control lions of both the sexes in summer and winter season, Gr-B: Control male lions in both the seasons, GrC: Male lions in summer season, Gr-D: Male lions in winter season, Gr-E: Control Female lions in both the seasons, Gr-F: Female lions in summer season and Gr-G: Female lions in winter season. 


\subsection{Housing and feeding}

The natural environment was provided with artificial hills and hideouts for housing of lions. The campus was rich in vegetation with trees, bushes and grass to protect from high temperature in summer and heavy rain in winter season. Artificial ponds as water sources were made to meet the specific needs of the animals. High wire mesh was constructed as protective measure for lions and visitors. The experimental animals were fed with the diet prescribed by the zoo management.

\subsection{Standard capture and sampling protocol}

The lions were kept in trap nest following standard capture protocol. Whole blood was collected from coccigeal veins before feeding in the morning time. Approximately $2 \mathrm{~mL}$ of blood was kept in sterile sampling vials with Ethylene Diamine Tetra Acetic acid and sodium fluoride (Merck India Ltd., Mumbai, India) for blood glucose estimation. Rest of the blood samples were kept in vials without any anticoagulant for 45 minutes at room temperature at the site of collection. The samples were kept in ice packed thermo cool bags and taken to laboratory. Non-hemolysed clear serum was collected by centrifugation (R-8C Laboratory centrifuges, REMI, India) at $2500 \mathrm{rpm}$ for 15 minutes. The serum samples were kept in sterilized plastic capped vials and preserved at $0-4^{\circ} \mathrm{C}$ for biochemical estimations. The samples were labeled with name of the animals as described in zoo record. The serum enzyme activities were estimated on the day of collection to prevent the effect of storage on them followed by estimation of other biochemical constituents and minerals.

\subsection{Biochemical analysis}

Glucose [3], Total protein [4], Albumin [5], Total cholesterol [6], Urea [7], Uric acid [8], Creatinine [9], Triglyceride [10], Total bilirubin [11], AST (Aspartate Aminotransferase) and ALT (Alanine Aminotransferase) [12], ALP (Alkaline Phosphatase) [13], LDH (Lactate Dehydrogenase) [14], Calcium [15] and Phosphorus [16] were estimated by following standard laboratory methods. The optical densities of blank, standard and test mixture were read in a LAMBDA $25 \mathrm{UV} / \mathrm{Vis}$ Spectrophotometers (Perkin Elmer, Switzerland). The chemicals used were from Merck India ltd., Mumbai, India.

\subsection{Statistical analysis}

The generated data was subjected to analysis of variance according to Snedecor and Cochran, [17] and significant values were calculated by using GraphPad Instat 3 software.

\section{Results}

The study of effects of summer and winter season on serum biochemical constituents, enzymes and major minerals of Panthera leo of NZP was conducted at three trial regimes of male (Table 1), female (Table 2) and both the sexes (Table 3 ) in comparison to their respective controls.

Male lions did not exhibit significant variations of all the parameters under study between seasons (Table 1). But female lions at Gr-G (Table 2$)$ depicted significantly $(p<0.01)$ elevated activity of ALP as compared to Gr-E. They also exhibited significantly $(p<0.001)$ lower levels of glucose and protein as compared to Gr-E in winter season. Further, in summer season the female lions at Gr-F showed significantly $(p<0.05)$ higher levels of urea with respect to its control group.

The comparative study (Table 3 ) in both the sexes and seasons of lions revealed significantly $(\mathrm{p}<0.001)$ higher contents of glucose in Gr-F lions in summer season. Gr-G animals in winter season displayed significantly declined levels of protein $(\mathrm{p}<0.001)$ and urea $(\mathrm{p}<0.01)$. The ALP activity was significantly higher $(\mathrm{p}<0.001)$ at Gr-D and G lions in winter season in comparison to those at Gr-A. Thus, the contents of glucose, protein, urea and ALP in lions vary significantly between sex and season.

\section{Discussion}

The biochemical constituents are the secretory/ excretory products of cellular metabolism and fractions of the dietary nutrients. They vary from normal to diseased animals within and between species, breed, sex, physiological states and geographical regions [18]. Endogenously synthesized hormones regulate the variations in blood chemistry of metabolites. These variations are also due to environmental and body factors. The observed values in the present study are in good agreement with the findings of Foster and Cunningham [19] in florida panthers, Srivastav et al. [20] and Chandranaik et al. [21] in tigers, Jani and Sabapara [22] and Jani et al. [23] in asiatic lions and Farooq et al. [24] in bengal tigers.

Glucose is the chief metabolic fuel for energy yield in carnivores. Its blood level depends on several factors such as type of diet and interaction of insulin, glucagon, epinephrine, thyroid, glucocorticoid, pituitary and sex hormones. The secretion of these hormones varies between season and sex. There is a positive corelation between blood glucose and temperature [25]. Basal Metabolic Rate (BMR) is regulated by 
environmental temperature and sex. In summer season significantly higher level of blood glucose in female lions at Gr-F is due to less utilization of glucose at low BMR at high temperature. But, lower glucose in male lions at Gr-C is because of high BMR and more utilization of glucose than females. The normal body temperature of female is more than that of male. More energy is required to maintain it in cold environment of winter season at low BMR. Here more glucose is spared for conservation of heat. Therefore female lions at Gr$\mathrm{G}$ exhibit low blood glucose in winter season.

In general, growth hormone, testosterone and estrogen are anabolic and thyroxin is catabolic in nature. Their actions alter serum proteins with respect to age, sex, breed, nutritional status and physiological condition.

Besides, nitrogen loss, increased adrenal activity and protein turn over resulting in decreased albumin and protein contents. Significantly low level of protein in Gr-G female lions in winter season is due to increased adrenal activity. The present findings go contrary to the reports of Erasmus [26] in African lions where no significant variations between sexes have been observed.

Serum urea is the nutritional indicator of nitrogen balance and protein metabolic status. Its blood concentration varies as per the availability and utilization of nitrogen. A positive nitrogen balance facilitates the individual to remain healthy in respect of growth and maintenance. In summer season, Nawaz and Shah [27] reports $30 \%$ higher urea values in sheep. In the present study, significant increased level of urea in female lions at Gr-F in summer season is due to more water loss and hemo-concentration under heat stress [27]. But the decreased value at Gr-G in winter season is due to the effect of renal tubal secretion [28].

Intracellular liver specific serum enzymes like AST, ALT and ALP are the units of cell metabolism. They take part in different metabolic path ways and exist either in free/ bound form. Any extent of membrane damage leads to leakage of these enzymes from cell. The extent of leakage correlates linearly to the degree of cell damage. These enzymes appear at higher levels in serum of male animals than in female ones due to more physical exercise and wear and tear. Generally their elevated levels in serum attribute to the alteration in architectural integrity of hepatocytes and muscle fibers. But, their declined levels are due to less endogenous synthesis. Significantly higher activity of ALP of lions at Gr-D and G in winter season is supported by Fowler and Miller, [29]. This is because; the surrounding lakes and hills keep the park more coldly during winter season. So, increased higher thyroid activity and BMR enhance plasma corticosteroid secretion to conserve body heat against cold stress [30].

\section{Conclusion}

The comparative study of serum constituents and enzymes of male and female lions in summer and winter season of NZP suggest for generating the basic clinical reference data for disease diagnosis in laboratory.

The concentrations of glucose, protein, urea and ALP activity vary significantly between sex and season. Therefore, these variations should be considered during diseases diagnosis.

\section{Acknowledgement}

We wish to acknowledge the technical support provided by the authority of Nanadankanan Zoological Park for collection of blood during this study. Also we acknowledge OUAT for necessary financial support conferred time to time for this study.

Table 1. Effect of season on serum biochemical constituents of male Panthera leo of Nanadankanan Zoological Park (Mean \pm SE).

\begin{tabular}{lccc}
\hline \multicolumn{1}{c}{ Parameters } & Gr-B & Gr-C & Gr-D \\
\hline Glucose (mg/dl) & $77.61 \pm 2.60$ & $76.06 \pm 3.20$ & $81.83 \pm 4.53$ \\
Protein (g/dl) & $7.86 \pm 0.11$ & $7.90 \pm 0.14$ & $7.77 \pm 0.14$ \\
Albumin (g/dl) & $3.36 \pm 0.10$ & $3.42 \pm 0.11$ & $3.19 \pm 0.21$ \\
Urea (mg/dl) & $143.20 \pm 5.69$ & $145.54 \pm 6.56$ & $137.09 \pm 12.10$ \\
Creatinine (mg/dl) & $1.60 \pm 0.07$ & $1.48 \pm 0.06$ & $1.63 \pm 0.14$ \\
Uric acid (mg/dl) & $1.18 \pm 0.10$ & $1.16 \pm 0.15$ & $1.20 \pm 0.04$ \\
Cholesterol (mg/dl) & $145.23 \pm 7.79$ & $137.33 \pm 7.83$ & $148.75 \pm 17.47$ \\
Triglyceride (mg/dl) & $85.23 \pm 13.71$ & $74.37 \pm 12.31$ & $77.48 \pm 14.79$ \\
Bilirubin (mg/dl) & $0.56 \pm 0.05$ & $0.53 \pm 0.08$ & $0.51 \pm 0.07$ \\
Calcium (mg/dl) & $11.52 \pm 0.32$ & $11.44 \pm 0.33$ & $11.71 \pm 0.83$ \\
Phosphorus (mg/dl) & $5.94 \pm 0.221$ & $5.96 \pm 0.26$ & $5.98 \pm 0.24$ \\
AST (IU/L) & $20.02 \pm 2.20$ & $18.48 \pm 1.64$ & $17.40 \pm 1.87$ \\
ALT (IU/L) & $12.39 \pm 1.35$ & $13.48 \pm 1.70$ & $13.76 \pm 1.78$ \\
ALP (IU/L) & $16.09 \pm 2.25$ & $13.18 \pm 2.30$ & $19.67 \pm 4.02$ \\
LDH (IU/L) & $118.10 \pm 14.92$ & $143.29 \pm 22.30$ & $112.72 \pm 13.51$ \\
\hline
\end{tabular}

Gr-B: Control male lions in both the seasons, Gr-C: Male lions in summer season, Gr-D: Male lions in winter season. 
Table 2. Effect of season on serum biochemical constituents of female Panthera leo of Nanadankanan Zoological Park (Mean \pm SE)

\begin{tabular}{lccc}
\hline \multicolumn{1}{c}{ Parameters } & Gr-E & Gr-F & Gr-G \\
\hline Glucose (mg/dl) & $102.78 \pm 5.52$ & $106.43 \pm 2.75$ & $86.00 \pm 6.50^{* * *}$ \\
Protein (g/dl) & $7.62 \pm 0.23$ & $7.38 \pm 0.10$ & $6.81 \pm 0.38^{* * *}$ \\
Albumin (g/dl) & $3.41 \pm 0.18$ & $3.45 \pm 0.11$ & $3.31 \pm 0.19$ \\
Urea (mg/dl) & $133.79 \pm 6.24$ & $144.16 \pm 5.25^{*}$ & $126.03 \pm 8.67$ \\
Creatinine (mg/dl) & $1.48 \pm 0.09$ & $1.51 \pm 0.08$ & $1.54 \pm 0.09$ \\
Uric acid (mg/dl) & $1.22 \pm 0.09$ & $1.13 \pm 0.10$ & $1.21 \pm 0.14$ \\
Cholesterol (mg/dl) & $150.32 \pm 12.80$ & $139.79 \pm 16.80$ & $158.22 \pm 19.59$ \\
Triglyceride (mg/dl) & $61.43 \pm 11.67$ & $67.52 \pm 13.98$ & $69.33 \pm 13.52$ \\
Bilirubin (mg/dl) & $0.47 \pm 0.07$ & $0.49 \pm 0.05$ & $0.51 \pm 0.06$ \\
Calcium (mg/dl) & $11.56 \pm 0.44$ & $10.86 \pm 0.76$ & $10.97 \pm 0.63$ \\
Phosphorus (mg/dl) & $5.65 \pm 0.19$ & $6.01 \pm 0.23$ & $5.81 \pm 0.31$ \\
AST (IU/L) & $18.29 \pm 1.53$ & $17.82 \pm 2.09$ & $19.21 \pm 2.41$ \\
ALT (IU/L) & $13.09 \pm 1.06$ & $13.82 \pm 1.46$ & $14.55 \pm 1.93$ \\
ALP (IU/L) & $14.56 \pm 3.76$ & $11.02 \pm 2.97$ & $24.71 \pm 3.21^{* *}$ \\
LDH (IU/L) & $103.73 \pm 11.35$ & $98.37 \pm 26.97$ & $108.52 \pm 14.47$ \\
\hline
\end{tabular}

Gr-E: Control female lions in both the seasons, Gr-F: Female lions in summer season and Gr-G: Female lions in winter season. Superscripts indicate significant variation $\left({ }^{*} \mathrm{p}<0.05,{ }^{* * *} \mathrm{p}<0.01\right.$ and $\left.{ }^{* * *} \mathrm{p}<0.001\right)$ between columns within the row.

Table 3. Effect of sex and season on serum biochemical constituents of Panthera leo of Nanadankanan Zoological Park (Mean \pm SE)

\begin{tabular}{|c|c|c|c|c|c|}
\hline & Control & $\mathrm{Su}$ & & & inter \\
\hline Parameters & Gr-A & $\mathrm{Gr}-\mathrm{C}$ & Gr-F & Gr-D & Gr-G \\
\hline Glucose (mg/dl) & $82.46 \pm 2.85$ & $\begin{array}{c}76.06 \pm 3.20 \\
(4.36 \downarrow)\end{array}$ & $\begin{array}{c}106.43 \pm 2.75^{* * *} \\
(29.06 \uparrow)\end{array}$ & $\begin{array}{c}81.83 \pm 4.53 \\
(0.76 \downarrow)\end{array}$ & $\begin{array}{c}86.00 \pm 6.50 \\
(4.29 \uparrow)\end{array}$ \\
\hline Protein (g/dl) & $7.65 \pm 0.12$ & $\begin{array}{c}7.90 \pm 0.14 \\
(3.27 \uparrow)\end{array}$ & $\begin{array}{c}7.38 \pm 0.10 \\
(3.53 \downarrow)\end{array}$ & $\begin{array}{c}7.77 \pm 0.14 \\
(1.57 \uparrow)\end{array}$ & $\begin{array}{c}6.81 \pm 0.38^{* * * *} \\
\quad(10.98 \downarrow)\end{array}$ \\
\hline $\operatorname{Albumin}(\mathrm{g} / \mathrm{dl})$ & $3.37 \pm 0.08$ & $\begin{array}{c}3.42 \pm 0.11 \\
(1.48 \uparrow)\end{array}$ & $\begin{array}{c}3.45 \pm 0.11 \\
(2.37 \uparrow)\end{array}$ & $\begin{array}{c}3.19 \pm 0.21 \\
(5.34 \downarrow)\end{array}$ & $\begin{array}{c}3.31 \pm 0.19 \\
(1.78 \downarrow)\end{array}$ \\
\hline Urea $(\mathrm{mg} / \mathrm{dl})$ & $140.56 \pm 4.47$ & $\begin{array}{c}145.54 \pm .56 \\
(3.54 \uparrow)\end{array}$ & $\begin{array}{c}144.16 \pm 5.25 \\
(2.56 \uparrow)\end{array}$ & $\begin{array}{c}137.09 \pm 12.1 \\
(2.47 \downarrow)\end{array}$ & $\begin{array}{c}126.03 \pm 8.67^{* *} \\
(10.34 \downarrow)\end{array}$ \\
\hline Creatinine (mg/dl) & $1.57 \pm 0.06$ & $\begin{array}{c}1.48 \pm 0.06 \\
(5.73 \downarrow)\end{array}$ & $\begin{array}{c}1.51 \pm 0.08 \\
(3.82 \uparrow)\end{array}$ & $\begin{array}{c}1.63 \pm 0.14 \\
(3.82 \uparrow)\end{array}$ & $\begin{array}{c}1.54 \pm 0.09 \\
(1.91 \downarrow)\end{array}$ \\
\hline Uric acid (mg/dl) & $1.19 \pm 0.08$ & $\begin{array}{c}1.16 \pm 0.15 \\
(2.52 \downarrow)\end{array}$ & $\begin{array}{c}1.13 \pm 0.10 \\
(5.04 \downarrow)\end{array}$ & $\begin{array}{c}1.20 \pm 0.04 \\
(0.84 \uparrow)\end{array}$ & $\begin{array}{c}1.21 \pm 0.14 \\
(1.68 \uparrow)\end{array}$ \\
\hline Cholesterol (mg/dl) & $146.65 \pm 6.53$ & $\begin{array}{c}137.33 \pm 7.83 \\
(6.35 \downarrow)\end{array}$ & $\begin{array}{c}139.79 \pm 16.80 \\
(4.67 \downarrow)\end{array}$ & $\begin{array}{c}148.75 \pm 17.47 \\
(1.43 \uparrow)\end{array}$ & $\begin{array}{c}158.22 \pm 19.59 \\
(7.89 \uparrow)\end{array}$ \\
\hline Triglyceride(mg/dl) & $72.19 \pm 13.84$ & $\begin{array}{c}74.37 \pm 12.31 \\
(3.01 \uparrow)\end{array}$ & $\begin{array}{c}67.52 \pm 13.98 \\
(6.46 \downarrow)\end{array}$ & $\begin{array}{c}77.48 \pm 14.79 \\
(7.32 \uparrow)\end{array}$ & $\begin{array}{l}69.33 \pm 13.52 \\
(3.96 \downarrow)\end{array}$ \\
\hline Bilirubin (mg/dl) & $0.54 \pm 0.06$ & $\begin{array}{c}0.53 \pm 0.08 \\
(1.85 \downarrow)\end{array}$ & $\begin{array}{l}0.49 \pm 0.05 \\
(9.26 \downarrow)\end{array}$ & $\begin{array}{l}0.51 \pm 0.07 \\
\quad(5.55 \downarrow)\end{array}$ & $\begin{array}{c}0.51 \pm 0.06 \\
(5.55 \downarrow)\end{array}$ \\
\hline Calcium (mg/dl) & $11.53 \pm 0.26$ & $\begin{array}{c}11.44 \pm 0.33 \\
(0.78 \downarrow)\end{array}$ & $\begin{array}{c}10.86 \pm 0.76 \\
(5.81 \downarrow)\end{array}$ & $\begin{array}{c}11.71 \pm 0.83 \\
(1.56 \uparrow)\end{array}$ & $\begin{array}{c}10.97 \pm 0.63 \\
(4.86 \downarrow)\end{array}$ \\
\hline Phosphorus (mg/dl) & $5.74 \pm 0.14$ & $5.96 \pm 0.26(3.83 \uparrow)$ & $\begin{array}{c}6.01 \pm 0.23 \\
(4.70 \uparrow)\end{array}$ & $\begin{array}{c}5.98 \pm 0.24 \\
(4.18 \uparrow)\end{array}$ & $\begin{array}{c}5.81 \pm 0.31 \\
(1.22 \uparrow)\end{array}$ \\
\hline AST (IU/L) & $18.17 \pm 2.89$ & $\begin{array}{c}18.48 \pm 1.64 \\
(1.70 \uparrow)\end{array}$ & $\begin{array}{c}17.82 \pm 2.09 \\
(1.92 \downarrow)\end{array}$ & $\begin{array}{c}17.40 \pm 1.87 \\
(4.23 \downarrow)\end{array}$ & $19.21 \pm 2.41(5.72 \uparrow)$ \\
\hline ALT (IU/L) & $12.29 \pm 2.46$ & $\begin{array}{c}13.48 \pm 1.70 \\
(9.68 \uparrow)\end{array}$ & $\begin{array}{c}13.82 \pm 1.46 \\
(12.44 \uparrow)\end{array}$ & $\begin{array}{c}13.76 \pm 1.78 \\
(11.96 \uparrow)\end{array}$ & $\begin{array}{c}14.55 \pm 1.93 \\
(18.38 \uparrow)\end{array}$ \\
\hline ALP (IU/L) & $12.21 \pm 1.95$ & $\begin{array}{c}13.18 \pm 2.30 \\
(7.94 \uparrow)\end{array}$ & $\begin{array}{c}11.02 \pm 2.97 \\
(9.74 \downarrow)\end{array}$ & $\begin{array}{c}19.67 \pm 4.02^{* * *} \\
(61.09 \uparrow)\end{array}$ & $\begin{array}{c}24.71 \pm 3.21^{* * *} \\
\quad(102.37 \uparrow)\end{array}$ \\
\hline LDH (IU/L) & $121.85 \pm 17.04$ & $\begin{array}{c}143.29 \pm 22.30 \\
(17.59 \uparrow)\end{array}$ & $\begin{array}{c}98.37 \pm 26.97 \\
(19.27 \downarrow)\end{array}$ & $\begin{array}{c}112.72 \pm 13.51 \\
(7.49 \downarrow)\end{array}$ & $\begin{array}{c}108.52 \pm 14.47 \\
(10.94 \downarrow)\end{array}$ \\
\hline
\end{tabular}

Gr-A: Control lions of both the sexes in summer and winter season, Gr-C: Male lions in summer season, Gr-F: Female lions in summer season, Gr-D: Male lions in winter season, and Gr-G: Female lions in winter season. Parentheses $(\uparrow) /(\downarrow)$ denote Percent increase / decrease in comparison to control Gr-A. Superscripts indicate significant variation $\left({ }^{*} \mathrm{p}<0.05,{ }^{* *} \mathrm{p}<0.01\right.$ and $\left.{ }^{* * *} \mathrm{p}<0.001\right)$ between columns within the row.

\section{References}

[1] C.K. Nielsen, M.J. Dowling, C.K. Miller, R.D. Wilson, H.G. Shaw, C.R. Anderson, and S.R. Wilson, Research and Educational Efforts by the Cougar Network, in D.E. Toweill, S. Nadeau, and D, Smith, (Ed.), Proc. 9th Mountain Lion international Workshop, Sun Valley, Idaho, USA, 2008, 250.

[2] P.M. Mahanta, P.C. Barman, and P. Hussain, Effect of season on some blood biochemical parameters of crossbred goats under two managemental systems, Indian Journal of Veterinary Medicine, 24, 2004, 49-51. 
[3] N. Nelson, A photometric adaptation of the Somogyi method for the determination of glucose, Journal of Biological Chemistry, $153,1944,375-380$

[4] O.H. Lowry, N.J. Rosebrough, A.L. Farr, and R.J. Randall, Protein measurement with the folin phenol reagent, Journal of Biological Chemistry, 193, 1951, 265-275.

[5] R.J. Bartholomew, and A.M. Delaney, Sulphonphthaleins as specific reagents for albumin: determination of albumin in serum, Proc. of the Australian Association of Clinical Biochemists, 1966, 214-218.

[6] A.C. Parekh, and D.H. Jung, Cholesterol determination with ferric acetate uranyl acetate and sulphuric acid-ferrous sulphate reagents, Analytical Chemistry, 42, 1970, 1423-1427.

[7] J.K. Fawcett, and J.E. Scott, A rapid and precise method for the determination of urea, Journal of Clinical Pathology, 13, 1960, 156-159.

[8] R.J. Henry, C. Sobel, and J. Kim, A modified carbonate-phosphotungstate method for the determination of uric acid and comparison with the spectrophotometric uricase method, American Journal of Clinical Pathology, 28, 1957, $152-160$.

[9] M.H. Roscoe, The Estimation of Creatinine in Serum, Journal of Clinical Pathology, 6, 1953, 201-207.

[10] M.W. McGowan, J.D. Artiss, D.R. Standberg, and B.A. Zak, Peroxidase-coupled method for the colorimetric determination of serum triglycerides, Clinical Chemistry, 29, 1983, 538-542.

[11] W.G. Dangerfield, and R. Finlayson, Estimation of bilirubin in serum, Journal of Clinical Pathology, 6, 1953, $173-177$.

[12] S. Reitman, and S. Frankel, A colorimetric method for the determination of serum glutamic oxalacetic and glutamic pyruvic transaminases, American Journal of Clinical Pathology, 28, 1957, 56-63.

[13] J. King, The Hydrolases-Acid and Alkaline Phosphatases, in D. Van (Ed.), Practical Clinical Enzymology, (Nostrand Company Ltd: London, 1965) 191-197.

[14] H. Varley, A.H. Gowenlock, and M. Bell, Practical Clinical Biochemistry (London: William Heinemann Books Ltd, 1991).

[15] W.W. Webster, The colorimetric determination of calcium, American Journal of Clinical Pathology, 37, 1962, 330-333.

[16] H.H. Taussky, and E. Shorr, A microcolorimetric method for the determination of inorganic phosphorus, Journal of Biological Chemistry, 202, 1953, 675-685.

[17] G.W. Snedecor, and W.G. Cochran, Statistical Methods (New Delhi: Oxford and IBH Publishing Co, 1994).

[18] N.Z. Gaikward, S.D. Despande, S.T. Bapat, and G.B. Parwe, Blood glucose and serum total protein levels in Jersey and Red Khadhari crossed cattle with reference to age, Indian Veterinary Journal, 69, 1992, 1091-1094.

[19] G.W. Foster, and M.W. Cunningham, Hematology and serum chemistry values for free ranging Florida panther's neonates with a comparison to adult panther values, Journal of Wildlife Disease, 45, 2009, 857-862.

[20] A.B. Shrivastav, K.P. Singh, S.K. Mittal, and P.K. Malik, Haematological and biochemical studies in tigers (Panthera tigris tigris), European Journal of Wildlife Reserach, 58, 2012, 365-367.

[21] B.M. Chandranaik, R. Rishikesavan, R. Sathish, K. Basavarajappa, P. Giridhar, and C. Renukaprasad, Studies on Serum Biochemical Values in Tigers (Panthera tigris), Zoos' print, 25, 2010, 26-27.

[22] R.G. Jani, and R.H. Sabapara, Serum biochemical study of major elements of captive Asiatic Lions Panthera leo persica. Journal of Threatened Taxa, 2, 2010, 724-727.

[23] R.G. Jani, R.H. Sabapara, and C.N. Bhuva, Reference values of serum biochemical elements of Asiatic lion (Panthera leo persica), Intas Polivet, 8, 2007, 525-528.

[24] U. Farooq, S. Sajjad, M. Anwar, and B.N. Khan, Serum Chemistry Variables of Bengal Tigers (Panthera tigris tigris) Kept in Various Forms of Captivity, Pakistan Veterinary Journal, 32, 2012, 283-285.

[25] A.S. Chahal, and P.J.S. Ratan, Studies on seasonal variations of some biochemical constituents of blood in Corriendale ram. Indian Veterinary Journal, 59, 1982, 931-936.

[26] H.L. Erasmus, Determination of some blood parameters in the African lion (Panthera leo), doctoral diss., University of the Free State, Bloemfontein, 2008.

[27] M. Nawaz, and B.H. Shah, Renal clearance of endogenous creatinine and urea in sheep during summer and winter, Research Veterinary Science, 36, 1984, 220-224.

[28] A.D. Watson, H.P. Lefebvre, D. Concordet, V. Laroute, J.P. Ferre, J.P. Braun, F. Conchou, and P.L. Toutain. Plasma exogenous creatinine clearance test in dogs: comparision with other methods and proposed limited sampling strategy, Journal of Veterinary Internal Medicine, 16, 2002, 22-33.

[29] M.E. Fowler, and R.E. Miller, Zoo and Wild Animal Medicine, (Philadelphia, USA: Saunders, 2003).

[30] A.T. Rao, and L.N. Acharjyo, Clinical problems in fields of Nandankanan Biological Park, Orissa, (Indian Zoo Year Book, 1996) $21-26$. 